\title{
Ideology and North-South Relations
}

\author{
JAGDISH BHAGWATI* \\ Columbia University, New York
}

\begin{abstract}
Summary. - North-South relations have been characterized by three ideological phases. The first started with a long period of ideological harmony, lasting into the early 1970s. It was interrupted by OPEC and the period of radical Southern ferment, to be followed by another, opposed divide when the United States shifted into conservative ideological posturing and actions with the first Reagan Administration. The second Reagan Administration's shift to the Baker Plan represents the third phase but can also be regarded as consistent with that ideological position.
\end{abstract}

\section{INTRODUCTION}

Most economists seek to retreat into a "value free" neutrality. Such neutrality is a dream or a nightmare, depending on your preferences; but in either case it remains a figment of one's imagination.

I propose to argue rather frontally instead that ideological perceptions, attitudes and preferences have defined the context in which important issues of political economy, affecting economic relations among the developing and the developed countries, have been debated and, in some critical areas, even decided upon. In particular, a long period of relative ideological harmony, lasting almost into the early $1970 \mathrm{~s}$, has been disturbed by two dramatic and altogether opposed ideological divides.

One resulted in the period of radical Southern ferment, in the aftermath of the OPEC successes in 1971 and 1973. The other followed thereafter, originating in the election of President Reagan in 1979 and defined by his Administration's policies in the first term which ushered in militant conservative activism, not merely at home but also in foreign economic policy.

Since the United States is a force majeure and despite all caveats the central actor on this scene, and since I believe that the recent shift in Southern postures towards moderation is endangered by our ideological posturing and actions which have replaced theirs, I will also underline the folly of our ways through President Reagan's first term. I will also take the opportunity to put into similar ideological perspective the recent actions of the Reagan Administration in its second term.

\section{HEGEMONY AND CONSENSUS}

Relations in the economic sphere, between the developing and the developed countries, evolved with substantial if diminishing tranquility until the early $1970 \mathrm{~s}$.

The ideology that provided the rationale and the cement during this postwar period was not universally shared, of course, by all actors in the international economy. But this was definitely a period of substantial hegemonic consensus around what we now call the Liberal International Economic Order (LIEO). International governance was provided by the Bretton Woods multilateral institutions which reflected the virtues of freer trade via the GATT. promoted capital flows to the developing countries via the World Bank and sought to provide the internal macroeconomic stability and external balance on which prosperity could be built, from the resulting trade and freed private capital flows and investments, via the IMF.

This consensus did, however, permit several accommodations that suited evolving changes in the structure of the world economy and in the number of countries emerging from colonial status into independence. But these changes did not constitute a fundamental change in the central thrust of the system.

\footnotetext{
*This is the text of the Bernard Fain Lecture delivered at Brown University on 18 April 1985. It has been revised and updated with the insertion of Section 4 in view of the important developments in US policy, popularly described as the "Baker Plan," which occurred after the Lecture was delivered.
} 
The newly formed developing countries were particularly conscious that the Bretton Woods structure was created when they did not exist as states and that while exit was politically infeasible and economically unwise, their voice was largely muted by voting arrangements that precluded a major role for them. They gradually clamored therefore to change these realities.

Again, the economic ideology of the Liberal International Economic Order increasingly found itself at odds with the challenge of accelerated development that faced the leaders in many developing countries The great economir historian, Alexander Gerschenkron, has hypothesized that the more economically backward a nation is, the greater will be the compulsion for the State to intervene and manage. He has forcefully argued this insight to be supported by historical evidence. There is little doubt that this factor fueled the desire of several developing countries to turn to protectionism, rather than free trade, ats they raced to increase their growth. and thus reduce their poverty, through industrialization in the early postwar decades.

But the basic premises of the Liberal International Economic Order were already being frayed somewhat at the margin in other areats of North-South interaction, such as foreign investment and skilled migration. It was argued, for instance, that the "benign neglect" under the Benthamite Bretton Woods structure may immiserize rather than enrich the developing countries - that therefore, it constituted in reality a "malign neglect" model and, in certain radical critiques, even a "malign intent" model. For example, multinational investments in developing countries were considered subversive instruments of neocolonial destabilization and control, while the "brain drain" from these countries was viewed as an unconscionable raiding of the Southern talents and human capital by the developed North. ${ }^{1}$ The Chilean economist. Oswaldo Sunkel, puts it aptly: integration into the world economy leads to disintegration of the national economy.

These differing intellectual viewpoints, departing from the ideological premises of the LIEO consensus, were, however, not the central tendency, at least among the important policymakers in most of the developing countries. The disharmony that they entailed in the LIEO framework was therefore quite manageable. And indeed it was managed by accommodating responses in the Bretton Woods institutions, responses which left the main system intact, in my judgement. ${ }^{2}$

Thus, at the GATT in particular, developing countries were accommodated in their principal demands. Part IV was introduced, virtually exempting them from much of the GATT discipline on MFN and GATT practice on reciprocity. This led the way to the granting of GSP (Generalized System of Preferences) through waiver of Article I of GATT. (But it also legitimated the excessive and unduly protracted protectionism that many of the developing countries practiced into the $1970 \mathrm{~s}$, resulting in their own failure to reap the rewards of more effective integration into an expanding world economy.

I consider these changes in GATT to bo accommodationist as the developing countries at the time were relatively unimportant in world trade and trade was growing by leaps and bounds anyway under CATT-spawned trade liberalization. One could even take the cynical view that, if developing countries wanted to shoot themselves in the foot by restricting their own trade, they should be given that privilege to continue as GATT members. Now, the story is quite different, of course. The end of the Golden Age of the 1950s and 1960s, and the rise of macroeconomic difficulties and attendant fueling of protectionist sentiments in the industrialized countries have prompted a reversal of these indulgent attitudes. GSP is no longer readily conceded. The newly industrialized developing countries - the NICs, or the SOUTHNICS as I prefer to characterize them for their aspiration to transit eventually from the ranks of the South to the North - are increasingly under pressure to "graduate." Again, the dogged sentiment in the United States for "fair trade" as against "free trade," substituting "aggressive reciprocity" for the traditional GATT-sanctioned reciprocity, extends increasingly to the SOUTHNICS as well. ${ }^{+}$

At the IMF, the accommodation took the form of creating low-conditionality facilities such as the Compensatory Financing Facility in 1963 and the Buffer Stock Facility in 1969. At the World Bank, the IFC (International Finance Corporation) was set up in 1956 and the IDA (International Development Agency), the astonishingly soft-loan facility, in 1960 .

At the institutional level. the response consisted in the creation in 1964 of the UNCTAD, a specialized UN agency to address the problems of the developing countries. While, in the last decade, precisely because of the ideological upheavals that I will presently describe, this agency has become anathema to the United States in particular, so that UNCIAD is treated as if it were UNWASHED and UNKEMPT, at the time of its creation it was viewed in far less alarming terms (though the United States did initially oppose its creation as unnecessary). As you doubtless feel overwhelmed by many of the 
acronyms I have put before you, let me entertain you by recounting how, when the United Nations Fund for Economic Development was set up, the word Special was desperately added to it so that, instead of UNFED, it would turn into SUNFED, suggesting the tropical luxuriance of SUNKIST oranges if not of the equatorial forests!

I would argue then that a broad, if necessarily fragile, consensus on the international economic management structure, or what we might call the superstructure defining the "governance of the world economy," did obtain through the 1950s and 1960s. Alongside this consensus was also a certain tolerance of differing political preferences of individual countries and for basic differences in the economic policy mix that these countries might choose. Thus, while the World Bank did. under Eugene Black's Presidency, indulge in sentiments against lending to public sector projects, this attitude was not long sustained. Mao Tse-tung evidently did not mean it when he asked for a hundred flowers to bloom. But the diversity of politics and economics that was tolerated by the hegemonic United States and other major actors in the corridors of power during the 1950s and $1960 \mathrm{~s}$ was a reality, in my judgement (though, as my radical friends will remind me, this tolerance often did not extend to those at the extreme left end of the political spectrum).

\section{THE FIRST IDEOLOGICAL DIVIDE}

The success of OPEC in the early 1970s shattered the prevailing consensus, ushering in the first of the two ideological upheavals that have afflicted North-South relations. There were three major ideological aspects to the OPEC model.

First, it suggested that unilateral action by developing countries, in concert, could redistribute income to them from the developed world. Compared to the voluntary, and in fact limited and declining redistribution through foreign aid, which depended on the altruism or enlightened self-interest of the North, such unilaterally extracted redistribution evidently had sex appeal. Besides, the numbers involved were truly colossal, giving redistribution a role equal to the traditional, growth-related, route to developmental objectives.

Second, unlike aid, such redistribution implied sovereignty in the use of the redistributed resources. This aspect had evident appeal to developing countries seeking greater control over their political destinies. I should say that OPEC"s success came at a time when economic aid had become increasingly tied to performance criteria.
While such strings are appropriate from an economic viewpoint, and are indeed inevitable when parliaments and congresses have to be convinced that aid is usefully spent, they have always created a diplomatic problem between donors and recipients. Indeed, by the early $1970 \mathrm{~s}$, the evolution of the performance criteria into detailed "conditionality" and monitoring by donors and by their occasional "aid consortia" had begun to cause considerable friction. The OPEC model cut through this difficulty: the earned redistribution of resources would be automatically free from conditionalities and strings.

Third, the route to success à la OPEC was through control over primary resources, and through the exercise of the power that followed therefrom. Both aspects had immediate ideological implications. Control would lend legitimacy to attempts at nationalization and, more weakly, to regulation and direction of the multinationals that were often in the primary, extractive industries of the developing countries. Exercise of the power from such control implied cartelization and utilization of the resulting monopoly power, as with OPEC. The former violated the premise of freer multinational investments, the latter the premise of free trade both ideologically at the center of the LIEO philosophy.

These perceptions were not simply intellectual: they had their counterpart in the international politics of North-South economic relations. They were thus to break the ideological, hegemonic consensus. A significant number of developing countries would now have an ideological conception that put them in a confrontational posture with the developed countries.

Also, the conflict would be militant. The perception of "commodity power" vis-à-vis the developed countries meant that the ideological differences could be translated into demands for negotiations on changes in the governance of the world economy. The LIEO era of consensus and of resource transfer by entreaty and moral suasion would now be replaced by demands for a New International Economic Order, the celebrated NIEO in the South but the infamous NIEO in the North. These demands would be made with a rhetoric that was often passionate; and the Suslovs of the NIEO, trained doubtless at the seats of learning in the North, would provide the articulation and substance to the rhetoric.

An important facet of this ideological divide (which was to help precipitate the second, ensuing and opposite ideological era) was the use of the United Nations as the forum for making 
these demands. This was perhaps inevitable as the United Nations is the natural meeting ground for diplomats who would be charged with pursuing the NIEO objectives. It was also an inevitable, preferred choice since the developing countries outnumber the developed there and votes are not weighted by wealth or its proxy, financial contributions.

But it did mean that the issues put into the NIEO demands would broaden to accommodate all, that focus and priorities would be lost, and that the interests of the powerful specialized agencies of Bretton Woods would be threatened. The unwieldiness of the NIEO demands, which embraced finance. aid, trade, and a host of other issues, was evident in the later demands for what came to be called Global Negotiation.s. Emerging from the Havana Nonaligned Movement (NAM) meeting in 1979, in the immediate aftermath of the second oil price increase of $80 \%$, these demands for Global Negotiations at the United Nations never got anywhere: the amibitious scope and contents of the NIEO-type meeting received an indifferent and at times contemptuous Northern response. Why?

The essential reason was that negotiations simply could not be conducted in the style or with the substance that the alleged "commodity power" was supposed to justify. It was manifest. already by the late 197()s, that bauxite and bananas were different from oil. Indeed, even OPEC was in distress, and beginning finally to have to act like a cartel, as the world economy stumbled into a major slump. The South was thus caught in an uncomfortable situation: its NIEO postures were predicated on a presumption of power that had heen illusory and was seen by the North clearly to be so.

A shift to moderate pragmatism was thus necessary. This clearly happened. admittedly with much recrimination and nostalgia, through 1983 and culminated in the New Delhi NAM meeting in March 1984.

\section{THE SECOND IDEOLOGICAL DIVIDE}

By this time, however, we were deeply into the militancy of the United States. The Reagan Administration's revisionist approach to NorthSouth relations was twofold.

Not only did it seek to reverse what it perceived as an ideological surrender to statism and intervention in the different multilateral agencies (via their very existence or through their methods of functioning), it also proceeded, in consequence, to become intolerant of the plur- alistic political and economic approaches to development.

The conviction with which the advantages of the invisible hand, and the disadvantages of the visible hand, were propagated and attempted to be imposed on the faithless infidels whenever possible. tempts one to describe this period as The Age of Certainty. It has also produced turbulence. Let me elaborate, taking the questions of multilateralism and the market ideology. in turn, as they border on North-South economic relations.

On multilateralism, I think it is fiir to say that the Administration has generally preferred the Bretton Woods institutions to the United Nations, has tried to reshape these institutions into at conservative image and, where necessary for its purpose, simply opted for the bilateral route, supplemented where feasible by groupings based on "like-minded" nations.

The conservative voice in the United States has turned steadily and standfastly against the United Nations in recent years. The confrontations over the NIEO between the G-77 (Group of 77 that represents the developing countries en bloc at the United Nations) and the US representatives from Senator Moynihan to Dr Jeane Kirkpatrick and her articulate aides have been as much a cause as a consequence of this anti-UN sentiment. The battles at UNESCO over the "information order," in which the western nations have been arguing at cross-purposes with the developing countries, and the resulting US withdrawal have heen a contributory factor. That the Soviet bloc often sides with the developing countries has been a sore point. The frequency of such "alignment" has been erroneously interpreted and denounced as the developing countries voting with the Soviet bloc. reducing the United States to a position of being "in opposition."

The following quotes, chosen from a multitude of such pronouncements, from the influential conservative think tank, the Heritage Foundation, illustrate my point. On the United Nations generally:

the work of the U.N. is more suspect than at any time in its history. It was not solely an exaggeration when James J. Kirkpatrick wrote on September 22, 1981 , in The Baltimore Sun that the "purpose /of the U.N.I as a forum has been reduced to nullity" and suggested that the media "should carry news of the U.N. back on the conic page's io deal with Doonesbury and his friends." There are questions, too, as to whether the U.S. is benefiting from its U. N membership, given the paralysis of the Security Council and the anti-American, anti-Western, anti-industrial, anti-capitalist majority in the General Assembly." 
More specifically, on economic issues and ideology:

Most dangerous ... is the U.N.'s de facto (and sometimes de jure) crusade against the free enterprise system. In many respects, the U.N. has become the headquarters, command post and strategic planning center of an anti-frec-enterprise campaign. In almost every U.N. body and almost always in the General Assembly, seldom is an opportunity lost to attack the free enterprise system.

And the U.N. crusade attacks the very essence and philosophical base of the free enterprise system. It is an assault which condemns almost always, without supporting evidence, the notion that the dynamo of growth and economic expansion is individual initiative, creativity and the incentive provided by the opportunity of making a profit. This kind of attack even repudiates the notion of economic growth, substituting for it the naive and economically self-defeating concepts of wealth redistribution and central planning. ${ }^{7}$ (Italics inserted)

The negative attitudes toward the United Nations have carried over into increasingly assertive ideological postures at multilateral economic agencies such as UNCTAD. The role that UNCTAD played in focusing early on important issues, such as tariff-escalation that generates high effective or value-added protection against developing countries, has been ignored and the "politicization" of the agency has been singled out for condemnation. ${ }^{8}$

If the United Nations has been discounted thus, the specialized agencies that constitute the central pillars of the Bretton Woods edifice have emerged as the arenas where the United States prefers to act. Correspondingly, there have been strong urges, and serious attempts, to purge these agencies of liberal heresies and any perceived conflicts with the play of market forces.

At the IMF, for example, the Administration has opposed the use of the Extended Facility (EF) which was set up originally in 1974 to provide longer-term finance to facilitate "structural adjustment." It also opposed, with not one member in support of this position, the granting of a substantial EF loan to India on the ideological ground that, despite the tragic experience of South America, India should first exploit private lending rather than turn to the IMF for such financing.

Again, on the Compensatory Financing Facility (CFF), the low-conditionality window at the IMF, the United States was primarily responsible for restricting its utility (since August 1979) by requiring that any borrowing in excess of $50 \%$ of the CFF quota could now occur only if the IMF were satisfied that the member country was cooperating with the IMF. By 1983, the conditions under which drawings could be made were changed towards virtually eliminating its softconditionality character."

On the debt situation generally, the Administration at first took the "benign neglect" view, asserting that laissez-faire would suffice. When the urgency of the debt situation became evident, there was a rush to the IMF to provide the necessary surveillance and conditionalitics and for its quotas to be increased. The Congress, having been duly briefed earlier on the Administration's criticisms of EF, CFF and other liberal excesses of the IMF, was now in the position of being told that the IMF should be strengthened to become the spearhead of the Administration's efforts to manage the debt crisis. "1

Until recently, the treatment of the World Bank was consistent with the ideological aspirations I have just detailed. The United States has been a principal advocate of extensive marketoriented conditionality on the Structural Adjustment Loans, the program of the Bank that is fraternal to the EF program of the IMF across the street (leading to inevitable jurisdictional tensions so that there is now an East-Bank-WestBank problem on the Potomac as well). It has also undermined efforts at IDA replenishment. Constituting the softest-loan window of the World Bank, of considerable value to the poorest countries, the IDA has always been a central component of Bank lending. The Administration dragged its feet, virtually in isolation, on IDA replenishment as late as 1984 , seeking a deep cut in the level of its operation.

Furthermore, bilateral initiatives and more narrowly multilateral efforts among "likeminded" nations have gained ground under the present Administration. Foreign aid has been dramatically refashioned in the Soviet image. Reflecting quid pro quo bilateralism, it is now increasingly and overwhelmingly bilateral, hugely tied into security ohjectives, and selectively channelled to countries of strategic value to the United States. The principal beneficiaries of the bilateral US aid program are no longer the poor nations, who are thus caught in the squeeze between multilateral efforts (such as the IDA) that are threatened by US opposition and a vastly diminished bilateral assistance. President Reagan is reputed to have admonished the developing countries at the Cancun Summit that development is a difficult business; evidently, his Administration's aid policies seem to be directed at ensuring that it remains that way!

The impatience with multilateralism and the desire to forge ahead with whomever will come on board is also manifest in some of the trade 
moves made by the Administration. The embrace of the European-style preferentialgrouping approach, as in the recent initiative for the Free Trade Area with Israel, the Caribbean Basin Initiative grant of discriminatory preferences, the bilateral deals on services with Israel and Canada, indicate a willingness to compromise the spirit of multilateralism. Some of these moves reflect a reaction to domestic protectionist pressures: others are responses to lobbies actively seeking markets abroad. But the overall political thrust towards bilateral moves is indeed laced by the militancy that is characteristic of the Administration: if other GATT members want to move slowly, we will bypass them and pursuc our trade objectives with anyone who comes along with us. Since US impatience is combined with a desire to extend GATT to a set of rules to facilitate private foreign investments, the militancy also has an ideological cutting edge.

The ideological assertiveness that animates these new directions in US policy towards multilateralism and international institutions is also manifest in the Administration's postures and actions clsewhere which show unabashed support of market approaches.

Thus, the Administration withdrew support from the carefully negotiated Law of the Sea Treaty because of its "statist" provisions concerning an international seabed authority and its powers. Again, it was the only nation that refused to sign the international convention that was adopted at the United Nations on guidelines for marketing baby food formula - a response to the tragic consequences caused by transplantation of developed-country marketing practices to the very different conditions in the developing countries.

At the 1984 Mexico Conference on population, the Administration insisted on the absurd doctrine that population growth would necessarily be benign in that it would automatically generate the income required to maintain itself. I call this a doctrinal shift from the hand-to-mouth theory of population in the poor countries to the hand-and-mouth theory! Again, it was a celebration of the doctrine that laissez-faire is ideal: it would produce not merely babies, but also the formula. pampers and cribs to take care of them. And the Earth had room for all! The other nations at the Conference were baffled by these assertions. They laughed in the corridors. But still they went along in the conference halls. yielding to the United States what it seemed to want so badly.

Indeed, the Administration succeeded in these ideological moves well beyond what one might have been led to believe by those who talk and write of the loss of US dominance and the rise of a multipolar power configuration in its place.

I believe that the reason is that the US has temporarily reverted to its dominant position in the world economy. The Reaganomics-induced world recession simultaneously broke OPEC power and reduced the Third World, especially the important debt-carrying countries, to a relatively impotent status. Western Europe has also been plagued by high levels of unemployment and a revival of stagnationist, defeatist doctrines. Japan is economically strong but heavily constrained by the growing xenophobia that its success has fed almost everywhere. Prudential acceptance of US positions, particularly when passionately held and of no direet consequenec to one's strategic interests (a condition not met by the Soviet gas pipeline episode where the Europeans stood up to US pressures). has thus been the rule.

\section{THE BAKER PLAN: AN IDEOLOGICAL QUICKSTEP}

The only silver lining to this black cloud, casting its shadow over North-South relations, has been provided by the dramatic shift in US policy towards the debt crisis. Mr Baker, the new Secretary of the Treasury, has faced up to the obvious folly of the policy of "malign neglect" of the international economy, by beginning to pull us back from the abyss that failure to intervene and to attempt coordination of economic policies among the major OECD countries implied e.g. via high interest rates and the overvaluation of the dollar. Equally, his initiative at the Seoul meeting of the IMF and the World Bank in October 1985, to shift the debt strategy from its deflationist, IMF-centered, hard-line approach to the World-Bank-centered soft-line approach has shown pragmatism and greater awareness of the needs of the debt-ridden countries, and a recognition that the hard-line policies were simply unworkable, counterproductive and imperiling the world economy as many had warned to no avail. ${ }^{11}$

But it is interesting that, even as Mr Baker has turned the first-term policies around on this question, the market ideology remains strongly in place, indeed even more explicitly so than to date. For, the added funds that $\mathrm{Mr}$ Baker seeks to galvanize and channel via the World Bank and other programs to the indebted countries, inadequate as they still are to the necessities, ${ }^{12}$ are explicitly to be made conditional on domestic measures to encourage the market forces, both 
domestic and the private foreign investments.

Hence, the widely-acclaimed shift to pragmatism is still cloaked in the ideological cloth that distinguished the rise of President Reagan. In fact, from a broader perspective, the Baker Plan itself can be construed as a creature of ideology - as a minimalist shift of the first-term strategy on debts required by the overheating of the debt crisis. It is worth noting that the Baker Plan surfaced when President Garcia of Peru had already acted with bravado and alacrity and President de la Madrid of Mexico was dropping alarming hints that, in the absence of net inflows such as those that the Baker Plan aims to generate, his acceptance of the hard-line conditionalities had been meaningless and that Mexico might opt for more radical solutions to the debt problem. The transition from the IMFcentered strategy still rejects the radical "non- market" solutions to the debt-overhang problem offered by many such as Professors Albert Fishlow and Peter Kenen and the New York financicr Felix Rohatyn. In fact, the new strategy represents a continuation of the market-oriented war on the debt problem by other means.

The ideological orientation of the Baker Plan is thus evident both in its origin and in the conditionalities it carries. It is thus a brilliant, ideological quick-step. President Reagan and his team have indeed responded to pragmatic reality. But they continue to fine-tune as they do so, yielding no more than they think they can get away with on the ideological front. The next turn of the screw, as the debt crisis hits the headlines again, should tell how far the Reagan Administration is prepared to go as its ideology confronts yet more disquieting realities.

\section{NOTES}

1. The concepts and themes touched upon here have been developed at greater length by me in two essays, reprinted in Bhagwati (1985a), Chaps. 1 and 2.

2. There is, of course, the classic problem of deciding whether the glass is half empty or half full. What I describe below, however, suggests definitely that the glass was more than half full. in support of my interpretation.

3. The losses from such protectionist excesses in the import-substituting countries have been set forth in detail in several empirical studies, including those conducted under major projects: the Little-ScitovskyScott OECD project, the Balassa IBRD project, and the Bhagwati-Krueger and Krueger NBER projects. The findings of most of these studies have been reviewed and synthesized in the Bhagwati-Srinivasan essay which is Chapter 6 in Bhagwati (1985a).

4. Traditional reciprocity implied matching of first differences, i.e. changes in levels of protection. Aggressive reciprocity implies matching of total levels of protection or openness of markets. The latter implies in practice a greater proneness to sectoral and bilateral trade approaches and a corresponding threat to multilateralism, not just to freer trade.

5. The phrasing is Moynihan`s. As careful scholars have noted, the Soviet Union often votes with G-77 on economic issues simply for political reasons but with absolutely no intention of assuming any of the multilateral obligations towards the developing countrics that the Resolutions in question require. See Padma Desai's (1984) analysis of the Soviet emphasis on what she aptly christens "quid pro quo bilateralism" as against assumption of multilateral economic obligations internationally.
6. Heritage Foundation (1978).

7. Heritage Foundation (1983).

8. The extensive range of the efforts which have been made to "take on" UNCTAD, and other UN agencies, has been noted in a frank and pointed speech delivered on 10 September 1984, by Ambassador Dubey, Permanent Representative of India to the UN Office in Geneva, a distinguished participant in the developmental activities and multilateral initiatives at the United Nations over two decades. These efforts have extended in his view to strong-arm tactics: "What is worse is that the trends of the UN institutions and other individuals holding important positions in them are being singled out for being maligned and made the target of bitter personal criticism. A systematic effort is being made to undermine the independence, objectivity and the initiative of these institutions by trying to determine in advance $[s i c]$ the kind of documents that they should produce."

9. In an important review of the CFF, tracing its evolution from 1963 to what is characterized as its "abolition" in 1983. Dell (1985, p. 245) has detailed how the "IMF decision of 14 September 1983, while it preserves the name CFF, destroys the basic purpose of the facility."

10. This episode has prompted a critic to remark: "Resentful of the Administration's flip-flop, Congress barely passed a multi-billion-dollar authorization. It was a long and bitter debate, which ultimately cast grave doubt on US support for the world's most effective financial organization. It would be a long time before Congress again approved new funds for the IMF." See Garten (1985), p. 553. 
11. I have exanined the factors that prompted the US moves in Bhagwati (1985b).

12. Professor Albert Fishlow has noted that the most optimistic numbers under the Baker Plan will make negligible net (of the overhang) funds available, over a limited period. to the indebted countries.

\section{REFERENCES}

Bhagwati, J., Dependence and Interdependence, ed. Gene Grossman (Oxford: Basil Blackwell, 1985a).

Bhagwati. J., "Investing abroad," Esmee Fairbairn Lecture presented at the University of Lancaster (27 November 1985b).

Dell, S., "The fifth credit tranche," World Development, Vol. 13. No. 2 (February 1985).

Desai, P., "The Soviet Union and the Third World: A faltering partnership?" in J. Bhagwati and J. R.
Ruggie (eds.), Power, Passions and Purpose: Prospects for North-South Negotiations (Cambridge: MIT Press, 1984).

Garten, J., "Gunboat economics," Foreign Affairs (Spring 1985).

Heritage Foundation, Backgrounder, No. $2 / 8$ (Washington. D.C. 21 January 1978).

Heritage Foundation, Backgrounder, No. 293 (Washington, D.C. 29 September 1983). 